\title{
Equine rhabdomyolysis: four clinical cases
}

\author{
Marianne M. Sloet van Oldruitenborgh-Oosterbaan', Robin van den Boom ${ }^{7}$ and Guy C. M. Grinwis ${ }^{2}$ \\ Department of Equine Sciences ${ }^{1}$ and Dept. of Pathobiology², Faculty of Veterinary Medicine, Utrecht University, Utrecht, The Netherlands
}

\begin{abstract}
Summary
Equine rhabdomyolysis is a potentially life-threatening myopathy with various underlying causes. After a short review of the literature on equine rhabdomyolysis, four clinical cases are discussed. One case was referred to the University clinic after the diagnosis had been made by the practitioner, two cases were referred for colic and one case for severe left hind limb lameness. All four horses proved to have rhabdomyolysis, showing myoglubinuria and serum creatine kinase activities between 56,000 and 400,000 IU/I and aspartate aminotransferase activities between 3500 and $7100 \mathrm{lU} / \mathrm{I}$. All four cases had increased blood glucose concentrations (between 8.1 and $13.1 \mathrm{mmol} / \mathrm{l}$ ) and increased blood lactate concentrations (between 2.8 and $10.4 \mathrm{mmol} / \mathrm{l}$ ). Treatment consisted of saline infusions, flunixin meglumine and acepromazine. Two horses recovered and went home. Two horses had to be euthanised and at post mortem examination showed macroscopic swelling and pallor of many muscles, which was characterised histologically by severe degeneration and necrosis of striated muscle tissue. The CK and AST activities did not prove useful in predicting the outcome, nor were the glucose or lactate concentrations. The most important factors for a favourable outcome are early recognition of the disease, absolute rest as soon as the diagnosis is made or suspected, and aggressive treatment.
\end{abstract}

Keywords: Rhabdomyolysis, muscle problems, Tying up, Monday morning disease, azoturia, myoglobinuria

\section{Die Rhabdomyolyse des Pferdes - 4 klinische Fälle}

Die Rhabdomyolyse des Pferdes ist eine potentiell lebensbedrohliche Myopathie mit unterschiedlichen Ursachen. Nach einem kurzen Überblick über die Literatur werden hier 4 klinische Fälle diskutiert. Ein Fall war nach der Diagnose durch den Haustierarzt, zwei Fälle wegen Kolik und einer wegen hochgradiger Lahmheit hinten links an die Universitätsklinik überwiesen worden. Alle 4 Pferde litten nachgewiesenermaßen an Rhabdomyolyse. Sie zeigten Myoglobinurie, Serumkreatinasewerte zwischen 56.000 und 400.000 IU/I und Asparat-Aminotransferase Aktivitäten zwischen 3.500 und 7.100 IU/l. Alle 4 Pferde hatten erhöhte Blutglucosewerte (zwischen 8,1 und 13,1 mmol/l) und erhöhte Blutlaktatkonzentrationen (zwischen 2,8 und 10,4 mmol/l). Die Behandlung bestand in $\mathrm{NaCl}$-Infusionen und der Applikation von Flunixin Meglumin und Azepromazin. Zwei Pferde erholten sich und konnten entlassen werden, die beiden anderen Tiere mussten euthanasiert werden. Die pathologische Untersuchung zeigte hier makroskopisch geschwollene und blasse Muskulatur, die histologisch durch starke Degeneration und Nekrose des quergestreiften Muskelgewebes charaktersisiert war. Weder die klinischen CK- und AST-Werte noch die Glukose- und Laktat-Konzentrationen wiesen auf den Verlauf der Fälle hin. Die wichtigste Voraussetzung für eine positive Entwicklung der Erkrankung ist die frühzeitige Diagnose, konsequente Ruhigstellung des Patienten sobald die Erkrankung erkannt ist oder vermutet wird, sowie eine Intensivbehandlung.

Schlüsselwörter: Rhabdomyolyse, Muskelprobleme, Tying up, Monday morning disease, Azoturie, Myoglobinurie, Verschlag

\section{Introduction}

Nowadays equine muscle disorders are increasingly important as more and more horses are subjected to a very irregular exercise schedule and fewer owners posses real horsemanship. For the veterinarian who first visits these cases it is of the utmost importance to recognise equine myopathy at an early stage, as transport of a patient with a muscle problem often results in a significant deterioration of the prognosis.

Exertional myopathy, chronic intermittent rhabdomyolysis, Monday morning disease, setfast, azoturia, tying up and paralytic myoglobinuria are all names for the same muscle problem (Beech 2000, Valberg 1996). The disease occurs worldwide, with an apparently random geographic distribution and may affect all breeds. Horses may experience exertional rhabdomyolysis for two main reasons: the horse has an underlying myopathy (chronic exertional rhabdomyolysis) or the horse has been overexerted physically (sporadic exertional rhabdomyolysis) (MacLeay 2004). Type II muscle fibres are most commonly affected (Beech 1997) and three major syndromes have been described as underlying cause: recurrent exertional rhabdomyolysis (RER) mainly in Thoroughbreds, polysaccharide storage myopathy (PSSM) mainly in Quarter horses and equine polysaccharide storage myopathy (EPSM) mainly in draft horses (MacLeay 2004). Risk factors influencing the occurrence of rhabdomyolysis include changes in training regimen (affected horses are often in regular work, rested for 1-2 days and then returned to work), excessive carbohydrate intake, high dietary potassium, excessive exercise of unfit horses and possibly inclement weather conditions, both hot and cold (Brown and Bertone 2002).

In the acute, often life-threatening phase of equine myopathy the underlying cause is of little relevance. Early recognition of the problem is of the utmost importance and is based on histo- 
ry, clinical examination, blood biochemistry (creatine kinase CK, aspartate aminotransferase - AST and sometimes lactate dehydrogenase - $\mathrm{LDH}$ ), and urine examination. Creatine kinase originates primarily from skeletal and cardiac muscle and is very specific for muscle problems. Aspartate aminotransferase and LDH are less specific as the concentration of these enzymes is high in skeletal and cardiac muscle as well as in the liver (Beech 1997). In practice, myoglobinuria (dark brown urine) is the quickest way to confirm the diagnosis.

Clinical signs of equine myopathy are highly variable (Beech 1997, Brown and Bertone 2002, Sloet and Goehring 2000) with some horses only demonstrating suboptimal performance and a slightly restricted gait. Occasionally, only a single limb is (severely) affected and these cases may be mistaken for a skeletal lameness. Some horses show weight shifting, an anxious expression and posturing as if to urinate when returned to their stall after exercise. Horses may also show abdominal discomfort or even colic as signs of exertional rhabdomyolysis. On palpation, affected muscles may be firm, swollen and painful but this is not always very clear. In severe cases a horse may show increased respiratory and heart rates, muscle fasciculations, trembling and profuse sweating, and may even collapse and be unable to rise. A division into three grades is possible, based on clinical symptoms and enzyme concentrations 1 to 4 hours after exercise:

- light form - transient muscle spasms or some abdominal discomfort, generally occurring after exercise; CK $<1500$ $\mathrm{IU} / \mathrm{I}$ and $\mathrm{AST}<500 \mathrm{IU} / \mathrm{I}$; no myoglobinuria

- intermediate form - sweating and stiffness occur, usually 20-30 minutes post-exercise; CK 1500-10,000 IU/I and AST 500-2000 IU/l; myoglobinuria is usually present

- severe form - occurs rapidly after the onset of exercise: profuse sweating and stiffness, trembling, fasciculations, sometimes recumbence and inability to rise; CK > 10,000 IU/I; AST concentration continues to rise for several days and may remain elevated for 15-28 days; myoglubinuria is always present

Although dark brown urine may be an indication of both haemoglobinuria and myoglobinuria, it is an important sign in horses with muscle stiffness. When the horse's serum is yellow, the dark brown urine is almost certainly due to myoglobin. Regrettably, there is still no specific and sensitive commercial test available for myoglobin.

Treatment of the acutely affected horse is based on alleviation of pain and anxiety, prevention of further muscle destruction and maintenance of fluid and electrolyte balance (Beech 1997). In severe cases therapy should be initiated before attempting to move the horse, because transportation may exacerbate the condition. Treatment of acute cases may consist of (Beech 1997, Bertone and Horspool 2004, MacLeay 2004, Sloet and Goehring 2000):

- Intravenous administration of polyionic fluids (in practice $\mathrm{NaCl} 0.9 \%$ will do) is necessary in all cases of myoglobinuria to prevent renal failure (oral administration of fluid is not advisable as horses with rhabdomyolysis often experience ileus)

- Sodium bicarbonate should not be given unless clinical laboratory data indicate that the horse is acidotic; most horses with rhabdomyolysis are alkalotic or have a normal blood $\mathrm{pH}$.

- Serum electrolytes should be monitored, but supplementation is rarely necessary and should never be given without specific laboratory data.

- Flunixin meglumine (1 mg/kg sid) is useful for its pain relief and anti-inflammatory properties, although some clinicians prefer ketoprofen $(0.5-2 \mathrm{mg} / \mathrm{kg}$ sid) or phenylbutazone (4 $\mathrm{mg} / \mathrm{kg}$ bid for $1-3$ days, then $2 \mathrm{mg} / \mathrm{kg}$ bid i.v. or p.o.).

- Acepromazine (0.02-0.03 mg/kg i.v. or i.m. qid) provides some tranquilisation and also peripheral vasodilation (care must be taken in hypovolemic patients). If more tranquilisation is required, the dosage of acepromazine can be increased (up to $0.1 \mathrm{mg} / \mathrm{kg}$ i.v. or i.m.); some clinicians prefer detomidine $(0.005-0.020 \mathrm{mg} / \mathrm{kg}$ i.v.) or phenobarbital (4-12 mg/kg i.v.).

- Alpha-tocopherol acetate (1.5-4 mg/kg p.o. sid; 1 mg vita$\min \mathrm{E}=1.3 \mathrm{IU}$ vitamin $\mathrm{E}$ ) may be useful, but probably mainly in the prevention of recurrence.

- In patients with extreme pain butorphanol (0.01-0.06 $\mathrm{mg} / \mathrm{kg})$, sometimes in combination with xylazine (0.3-0.6 $\mathrm{mg} / \mathrm{kg}$ ), may be necessary.

Prevention of further episodes of exertional myopathy in susceptible horses should include standardised daily exercise routines and an environment that minimises stress (Valberg 1996). The diet should include a balanced vitamin and mineral supplement, high-quality hay, and a minimum of carbohydrates such as grain and concentrates; dietary fat can be supplemented if needed to maintain the horse's body condition (Valberg 1996). Some clinicians prescribe dantrolene (2-4 $\mathrm{mg} / \mathrm{kg}$ orally, 1 hour before exercise) or phenytoin (1.4-8 $\mathrm{mg} / \mathrm{kg}$ bid p.o.; check serum levels) (Beech 1997, Valberg 1996). Dantrolene inhibits calcium release from the sarcoplasmic reticulum in muscle and phenytoin affects ion channels. Both drugs are reported to be effective in the prophylaxis of exertional rhabdomyolisis (Beech 1997, Valberg 1996), but both drugs are expensive and are considered as doping in sport horses. To illustrate the problems in diagnosing rhabdomyolysis, the importance of early recognition and the results of therapy, four clinical cases are described.

\section{Case A}

On May 2, a four-year old Shetland pony mare $(217 \mathrm{~kg})$ was referred to the University clinic with the owner complaining that this afternoon, during a pleasure ride, the pony became stiff. The pony took small steps with the hind limbs and showed kyphosis. The referring veterinarian performed a clinical examination and found a heart rate of 60 beats/min, with a normal respiratory rate and rectal temperature. Nasogastric intubation did not yield any gastric reflux and rectal palpation revealed no abnormalities. The clinical signs were considered to be due to 'colic' and the owner was instructed to handwalk the pony. Within an hour the pony became very reluctant to bear weight on the left hind limb and only wanted to lie down. At that point the mare was referred to the University clinic at the owner's request.

On arrival the pony was recumbent and unable to stand, only managing to assume a 'dog sitting position'. The respiratory rate was 24 breaths/min, the heart rate 72 beats $/ \mathrm{min}$ 
and the rectal temperature $38.2^{\circ} \mathrm{C}$. One moment it was feared that the signs may be caused by the neurological form of EHV1. However, the mare had a strong tail tone and on palpation the lumbar and gluteal muscles seemed hard and sensitive. Considering the history and clinical examination, a tentative diagnosis of equine rhabdomyolysis was reached. To confirm this diagnosis the urinary bladder was catheterised and dark brown urine obtained. A blood sample from the jugular vein revealed yellow plasma, indicating that the urine contained myoglobin and not haemoglobin (Figure 1).

Blood examination revealed slightly elevated packed cell volume (PCV), a decreased $\mathrm{pH}$, an increased blood glucose concentration and a very high blood lactate concentration (Table 1). A permanent catheter was placed in one of the jugular veins and a saline solution was administered at a rate of $8 \mathrm{ml} / \mathrm{kg} /$ hour for the first 3 hours, $4 \mathrm{ml} / \mathrm{kg} /$ hour for the next nine hours (Figure 2) and $2 \mathrm{ml} / \mathrm{kg} /$ hour for another 2 days. In addition, the mare was treated with flunixine meglu-

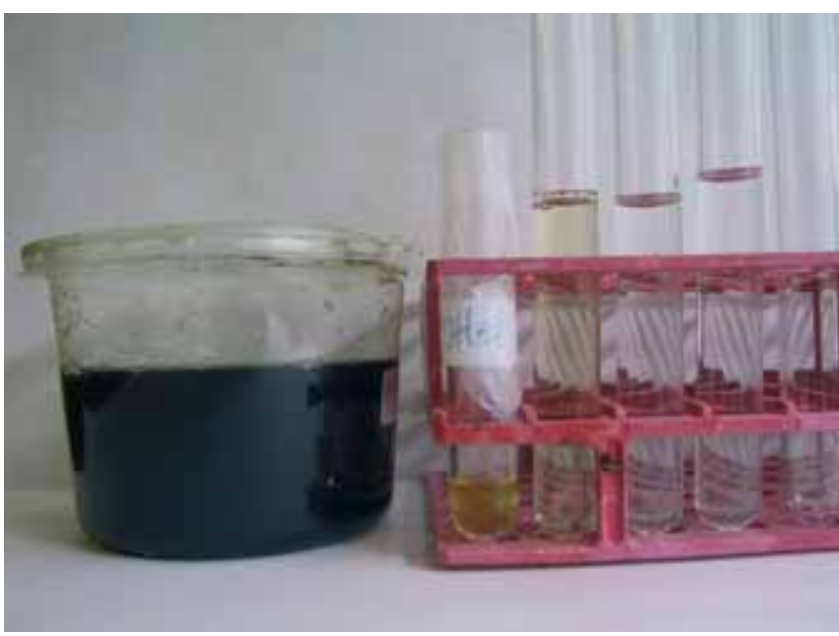

Fig 1 Dark brown urine and yellow plasma of patient $A$, on arrival on May 2

Dunkelbrauner Urin und gelbes Plasma von Patient A zum Zeitpunkt der stat. Aufnahme am 2. Mai. mine $^{1}$ (1 mg/kg i.v. sid) as an NSAID, acepromazine ${ }^{2}(0.04$ $\mathrm{mg} / \mathrm{kg}$ i.v. qid, mainly to obtain peripheral vasodilatation and also some sedation), and trimethoprim sulfadoxine ${ }^{3}$ (30 $\mathrm{mg} / \mathrm{kg}$ i.v. bid), to prevent infection of the bladder following catheterisation in a recumbent mare.

The mare made several unsuccessful attempts to rise but did not panic as long as someone was with her in the stall. Although the University clinic does normally not allow owners to stay with their horses, we made an exception in this case as it became clear that the pony remained perfectly calm as long as the owner was with it in the stall and that it started to struggle in attempts to rise as soon as it was left alone. The mare

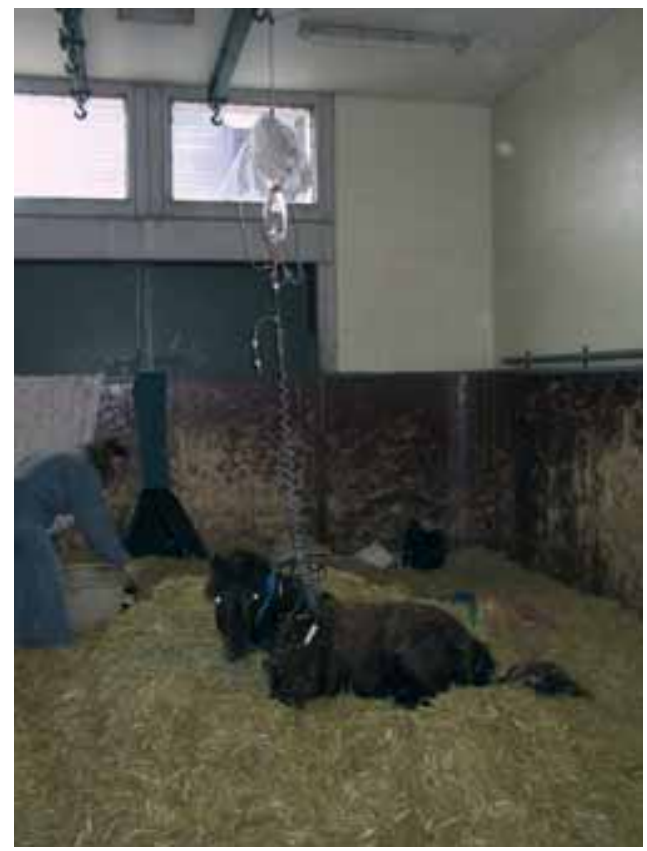

Fig 2 Patient A on May 2 with a saline drip lying quietly on a thick straw bed.

Patient $\mathrm{A}$ am 2. Mai liegt unter $\mathrm{Na}$-Cl-Infusion ruhig auf einer dicke Strohmatraze.

Table 1 Haematology and blood biochemistry of patient A. n.d. = not determined. Hämatologie und Blutchemie von Patient A. n.d. =nicht untersucht

\begin{tabular}{|c|c|c|c|c|c|c|c|c|}
\hline & $\begin{array}{l}2 / 5 \\
21.00 \\
\end{array}$ & $\begin{array}{l}2 / 5 \\
24.00 \\
\end{array}$ & $\begin{array}{l}3 / 5 \\
09.00\end{array}$ & $\begin{array}{l}5 / 5 \\
09.00\end{array}$ & $\begin{array}{l}6 / 5 \\
09.00\end{array}$ & $\begin{array}{l}13 / 5 \\
09.00\end{array}$ & $\begin{array}{l}19 / 5 \\
09.00\end{array}$ & $\begin{array}{c}\text { Reference } \\
\text { values }\end{array}$ \\
\hline PCV (I/I) & 0.43 & 0.26 & 0.30 & 0.26 & 0.30 & n.d. & n.d. & $0.32-0.42$ \\
\hline WBC $(G / I)$ & 10.6 & 6.5 & 6.8 & 13.4 & 13.5 & n.d. & n.d. & 7.0-10.0 \\
\hline $\mathrm{pH}$ & 7.230 & 7.306 & 7.365 & 7.390 & n.d. & n.d. & n.d. & $7.35-7.45$ \\
\hline $\mathrm{pCO}_{2}(\mathrm{kPa})$ & 7.2 & 6.8 & 6.5 & 6.3 & n.d. & n.d. & n.d. & $4.7-6.0$ \\
\hline $\mathrm{HCO}_{3}-(\mathrm{mmol} / \mathrm{l})$ & 22.5 & 24.7 & 27.2 & 28.3 & n.d. & n.d. & n.d. & $20-28$ \\
\hline $\mathrm{BE} \quad(\mathrm{mmol} / \mathrm{l})$ & -5.4 & -1.9 & 1.5 & 3.0 & n.d. & n.d. & n.d. & -3 to +3 \\
\hline Lactate $(\mathrm{mmol} / \mathrm{I})$ & 10.4 & 3.1 & 2.2 & 2.1 & n.d. & n.d. & n.d. & $0.7-1.2$ \\
\hline CK $\quad(\mathrm{mmol} / \mathrm{l})$ & 400,000 & n.d. & 180,000 & 40,000 & 6978 & 246 & 148 & $<200$ \\
\hline AST $(\mathrm{mmol} / \mathrm{I})$ & 6884 & n.d. & n.d. & 7100 & 6015 & 1742 & 879 & $125-275$ \\
\hline Glucose ( $\mathrm{mmol} / \mathrm{l})$ & 12.4 & 18.1 & 8.2 & n.d. & n.d. & n.d. & n.d. & $3.9-5.6$ \\
\hline $\mathrm{Na}^{+}(\mathrm{mmol} / \mathrm{l})$ & 136 & 135 & 139 & n.d. & n.d. & n.d. & n.d. & $135-150$ \\
\hline $\mathrm{K}^{+}(\mathrm{mmol} / \mathrm{l})$ & 2.7 & 3.0 & 3.9 & n.d. & n.d. & n.d. & n.d. & $3.0-5.9$ \\
\hline $\mathrm{Cl}^{-}(\mathrm{mmol} / \mathrm{l})$ & 92 & 102 & 103 & n.d. & n.d. & n.d. & n.d. & $96-107$ \\
\hline $\mathrm{Ca}^{++}(\mathrm{mmol} / \mathrm{l})$ & 0.9 & 1.2 & 1.3 & n.d. & n.d. & n.d. & n.d. & $1.4-1.7$ \\
\hline
\end{tabular}


was fed hay and positioned on alternating sides every two to four hours. The next morning, May 3, the mare was still not able to stand but she managed to rise for a few seconds now and then and lie down on her other side. In between attempts

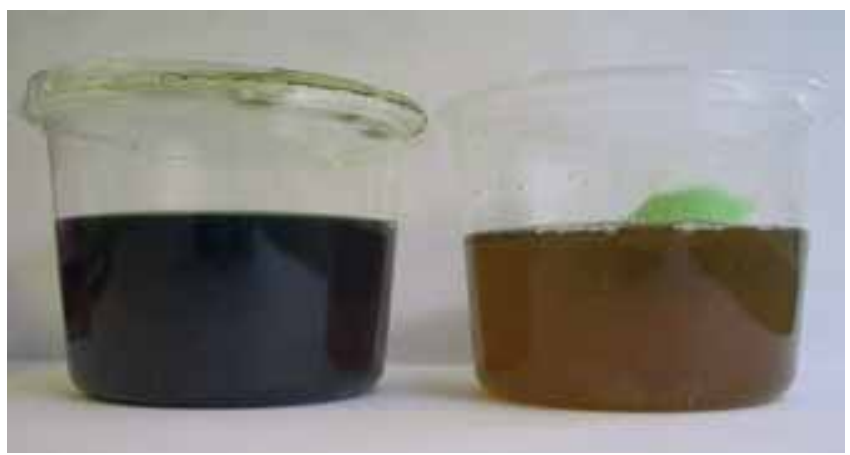

Fig 3 The urine of patient A on May 2 (dark brown) and on May 4 (dark yellow)

Urin von Patient A am 2. Mai (dunkelbraun) und am 4. mai (dunkelgelb).

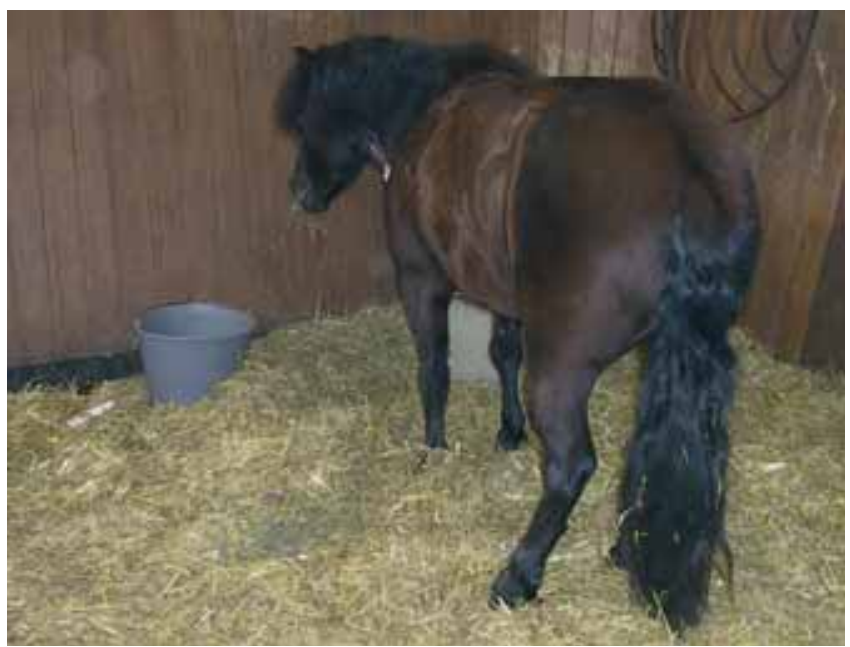

Fig 4 Patient A on May 6, still very lame on left hind limb Patient A am 6. Mai, hi li noch stark lahm.

to rise she remained very calm as long as the owner was in the stall. The urine was now dark yellow (Figure 3).

On May 5, the mare was able to rise by herself and was even able to stand for short periods. She was severely lame on her left hind limb (Figure 4), but could be left alone without any problem. The saline, TMPS, flunixin meglumine and acepromazine treatments were stopped and NSAID treatment was continued with vedaprofen ${ }^{4}(2 \mathrm{mg} / \mathrm{kg}$ p.o. bid on the first day and $1 \mathrm{mg} / \mathrm{kg}$ bid on the following days). Further, tocopherol acetate 5 (3,5 mg/kg/day p.o.) was administered twice a day.

Over the following weeks the CK and AST concentrations decreased further (Table 1). The mare walked around in her stall $(5 \times 10 \mathrm{~m})$, and was hand-walked from May 19 on. On May 23 the pony walked and trotted without residual lameness and went home.

\section{Case B}

On October 25, a 7-year old Fiord gelding (505 kg) was referred to the University clinic with the tentative diagnosis of rhabdomyolysis. On October 18, the horse had been turned out in a new, large field and the owner had not be able to catch it for a week, and thus the horse had not been ridden during this time. On the morning of October 25, the owner had succeeded in catching the horse and had started a trail ride. After 20 minutes the horse's gait was stiff and the horse showed a very tucked up abdomen. The owner decided to go home immediately at a slow walk. Back at the stable the horse was sweating profusely and showed muscle tremors. The referring veterinarian administered a large dose of a NSAID but after 3 hours the horse had not improved, being dull and showing muscle fasciculations. At that point it was referred to the University clinic and during transport the horse urinated 'dark-coffee-like' urine and defecated normally.

On arrival on October 25, the horse showed a stiff gait, severe muscle trembling and profuse sweating (Figure 5). The respiratory rate was 20 breaths/min, the heart rate was 72 beats/min and the rectal temperature was $37.8^{\circ} \mathrm{C}$. The muscles of the back and the hindquarters were painful. A saline

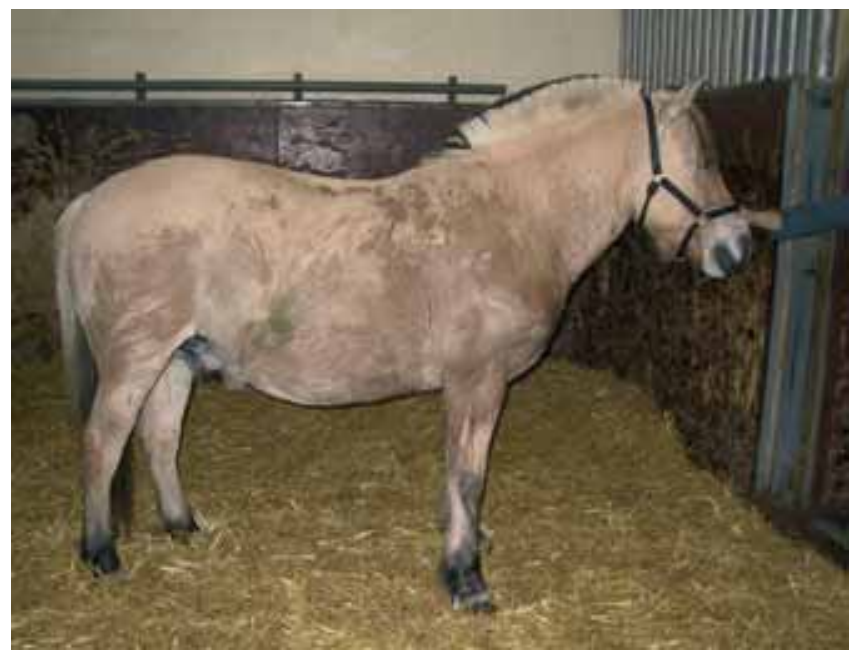

Fig 5 Patient B on arrival in the University clinic Patient B zum Zeitpunkt der stat. Aufnahme.

infusion was started at $4 \mathrm{ml} / \mathrm{kg} / \mathrm{hour}$ and the horse was treated with acepromazine $(0.05 \mathrm{mg} / \mathrm{kg}$ i.v. qid).

The next morning, October 26, the horse was much better, the heart rate was 44 beats/min, the horse behaved normally and no trembling or sweating was present. The lumbar and gluteal muscles seemed less painful on palpation. The infusion rate was decreased to $2 \mathrm{ml} / \mathrm{kg} /$ hour and acepromazine treatment was continued (until October 31). Treatment with flunixine meglumine $(1 \mathrm{mg} / \mathrm{kg}$ sid until November 4) and tocopherol acetate $(3,5 \mathrm{mg} / \mathrm{kg} /$ day p.o.) were started.

On October 27, the horse was alert, eating its hay very well and intravenous fluid administration was discontinued. On October 29, the horse behaved completely normal and was eating well. However, there were some signs of a developing peri/thrombophlebitis at the catheter site. This was confirmed by ultrasonographic examination and treatment with trimethoprim sulphadoxine i.v. (30 mg/ $\mathrm{kg}$ once) was started and this was continued orally with trimethoprim sulfadiazine ${ }^{6}$ (30 $\mathrm{mg} / \mathrm{kg} \mathrm{bid}$ ). Further, heparin ${ }^{7}$ (40 IU/kg s.c. qid) and calcium carbasalate $^{8}(10 \mathrm{mg} / \mathrm{kg}$ p.o. sid on the first day and $5 \mathrm{mg} / \mathrm{kg}$ 
Table 2 Haematology and blood biochemistry of patient B. n.d. = not determined. Hämatologie und Blutchemie von Patient B. n.d.=nicht untersucht

\begin{tabular}{|c|c|c|c|c|c|c|c|c|c|}
\hline & $\begin{array}{l}25 / 10 \\
18.00\end{array}$ & $\begin{array}{l}26 / 10 \\
09.30\end{array}$ & $\begin{array}{l}27 / 10 \\
08.00\end{array}$ & $\begin{array}{l}29 / 10 \\
08.00\end{array}$ & $\begin{array}{l}30 / 10 \\
08.00\end{array}$ & $\begin{array}{l}5 / 11 \\
08.00\end{array}$ & $\begin{array}{l}10 / 11 \\
08.00\end{array}$ & $\begin{array}{l}12 / 11 \\
08.00\end{array}$ & $\begin{array}{c}\text { Reference } \\
\text { values }\end{array}$ \\
\hline PCV (I/I) & 0.31 & 0.20 & 0.25 & n.d. & n.d. & 0.29 & nd & nd & $032-0.42$ \\
\hline WBC (G/I) & 7.6 & 4.5 & 5.2 & 6.9 & 4.0 & 5.9 & n.d. & n.d. & 7.0-10.0 \\
\hline $\mathrm{pH}$ & 7.430 & 7.376 & n.d. & n.d. & n.d. & n.d. & n.d. & n.d. & $7.35-7.45$ \\
\hline $\mathrm{pCO}_{2}(\mathrm{kPa})$ & 5.8 & 6.5 & n.d. & n.d. & n.d. & n.d. & n.d. & n.d. & $4.7-6.0$ \\
\hline $\mathrm{HCO}_{3}^{-}\left(\mathrm{mmol}^{\prime} \mathrm{I}\right)$ & 28.2 & 28.1 & n.d. & n.d. & n.d. & n.d. & n.d. & n.d. & $20-28$ \\
\hline $\mathrm{BE} \quad(\mathrm{mmol} / \mathrm{l})$ & 4.0 & 2.5 & n.d. & n.d. & n.d. & n.d. & n.d. & n.d. & -3 to +3 \\
\hline Lactate $(\mathrm{mmol} / \mathrm{l})$ & 5.2 & 1.1 & 1.0 & n.d. & n.d. & n.d. & n.d. & n.d. & $0.7-1.2$ \\
\hline CK (mmol/l) & 56,173 & 18,551 & 8989 & 2267 & 701 & 215 & n.d. & 128 & $<200$ \\
\hline AST $(\mathrm{mmol} / \mathrm{I})$ & 3380 & 3568 & 3360 & 3242 & n.d. & 1323 & 845 & 634 & $125-275$ \\
\hline Glucose $(\mathrm{mmol} / \mathrm{l})$ & 11.0 & n.d. & n.d. & n.d. & n.d. & n.d. & n.d. & n.d. & $3.9-5.6$ \\
\hline Urea (mmol/l) & n.d. & n.d. & 3.8 & 5.0 & n.d. & n.d. & n.d. & n.d. & $<8$ \\
\hline $\mathrm{Na}^{+}(\mathrm{mmol} / \mathrm{l})$ & 136 & 141 & 138 & n.d. & n.d. & n.d. & n.d. & n.d. & $135-150$ \\
\hline $\mathrm{K}^{+}(\mathrm{mmol} / \mathrm{l})$ & 4.4 & 3.1 & 4.5 & n.d. & n.d. & n.d. & n.d. & n.d. & $3.0-5.9$ \\
\hline $\mathrm{Cl}^{-}(\mathrm{mmol} / \mathrm{l})$ & 104 & 107 & 109 & n.d. & n.d. & n.d. & n.d. & n.d. & $96-107$ \\
\hline $\mathrm{Ca}^{++}(\mathrm{mmol} / \mathrm{I})$ & 1.1 & 1.1 & 1.5 & n.d. & n.d. & n.d. & n.d. & n.d. & 1.4-1.7 \\
\hline
\end{tabular}

sid thereafter) were given. In addition, the jugular vein region was hosed with cold water four times a day.

The stiffness and sensitivity of the muscles disappeared during the following days. However, the peri/thrombophlebitis failed to improve. A blood culture on October 29 had shown no bacterial growth. Still, it was decided to change the antibiotic treatment to ceftiofur ${ }^{9}(5 \mathrm{mg} / \mathrm{kg}$ i.m. bid) and to add vedaprofen (2 mg/kg p.o. bid on the first day and $1 \mathrm{mg} / \mathrm{kg}$ bid on the following days) as an NSAID. The peri/thrombophlebitis reacted very well to this change in medication, and on November 4 the ceftiofur and vedaprofen treatment could be stopped.

From November 10 the horse was hand-walked for increasing periods, starting with 5 minutes per day and building up up to
$6 \times 5$ minutes per day. The horse went home on November 14, and the owner was advised to continue the treatment with vitamin $\mathrm{E}$ for an extended period, to continue hand-walking the horse further and to feed the horse a restricted ration. The advice to the referring veterinarian was to check the muscle enzymes after a week and then increase the training programme.

\section{Case C}

On October 18, a 6 year-old Groninger gelding (estimated weight $550 \mathrm{~kg}$ ) was referred to the University clinic with a history of colic and lethargy since a few days. The horse had been recumbent the entire night before referral. The referring

Table 3 Haematology and blood biochemistry of patient C. n.d. = not determined.

Hämaotologie und Blutchemie von Patient C. n.d.=nicht untersucht

\begin{tabular}{|c|c|c|c|c|}
\hline & $18 / 10$ & $19 / 10$ & $20 / 10$ & Reference values \\
\hline PCV $(I / I)$ & 0.43 & 0.45 & 0.38 & $0.32-0.42$ \\
\hline WBC $(G / I)$ & n.d. & 6.2 & 7.3 & 7.0-10.0 \\
\hline $\mathrm{pH}$ & 7.353 & 7.430 & 7.437 & $7.35-7.45$ \\
\hline $\mathrm{pCO}_{2}(\mathrm{kPa})$ & 6.1 & 6.2 & 6.3 & $4.7-6.0$ \\
\hline $\mathrm{HCO}_{3}^{-}(\mathrm{mmol} / \mathrm{l})$ & 25.1 & 31.0 & 31.1 & $20-28$ \\
\hline $\mathrm{BE} \quad(\mathrm{mmol} / \mathrm{l})$ & -0.4 & +6.0 & +6.4 & -3 to +3 \\
\hline Lactate $(\mathrm{mmol} / \mathrm{l})$ & n.d. & 3.5 & 6.8 & $0.7-1.2$ \\
\hline CK $(\mathrm{mmol} / \mathrm{l})$ & 179,619 & n.d. & 236,895 & $<200$ \\
\hline AST $(\mathrm{mmol} / \mathrm{I})$ & 6779 & n.d. & 17,516 & $125-275$ \\
\hline $\mathrm{LDH} \quad(\mathrm{mmol} / \mathrm{l})$ & 18,281 & n.d. & n.d. & $150-420$ \\
\hline$\gamma$-GT $(\mathrm{mmol} / \mathrm{l})$ & 18 & n.d. & n.d. & $<20$ \\
\hline Glucose $(\mathrm{mmol} / \mathrm{l})$ & 13.1 & 9.9 & 8.1 & $3.9-5.6$ \\
\hline Urea $(\mathrm{mmol} / \mathrm{l})$ & n.d. & 8.8. & n.d. & $<8$ \\
\hline $\mathrm{Na}^{+}(\mathrm{mmol} / \mathrm{l})$ & n.d. & 141 & 143 & $135-150$ \\
\hline $\mathrm{K}^{+}(\mathrm{mmol} / \mathrm{l})$ & n.d. & 3.7 & 4.3 & $3.0-5.9$ \\
\hline $\mathrm{Cl}^{-}(\mathrm{mmol} / \mathrm{l})$ & n.d. & 93 & 96 & $96-107$ \\
\hline $\mathrm{Ca}^{++}(\mathrm{mmol} / \mathrm{l})$ & n.d. & 0.9 & 1.0 & $1.4-1.7$ \\
\hline
\end{tabular}


veterinarian gave the horse a large dose of an NSAID to enable transport of the horse to the University clinic by trailer.

On arrival the horse was severely ataxic and was hardly able to stand. Respiratory rate was 20 breaths/min, heart rate was 60 beats/min and the rectal temperature $37.3{ }^{\circ} \mathrm{C}$. Nasogastric intubation did not yield any gastric reflux. Rectal palpation revealed no abnormalities, although the rectum contai-

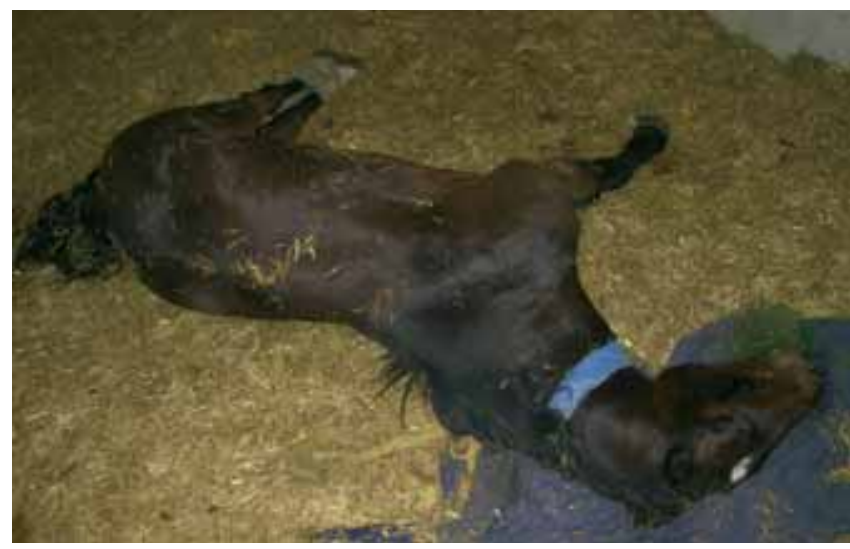

Fig 6 Patient $C$ on October 19, lying down and unable to rise. Patient $\mathrm{C}$ am 19. Oktober, festliegend

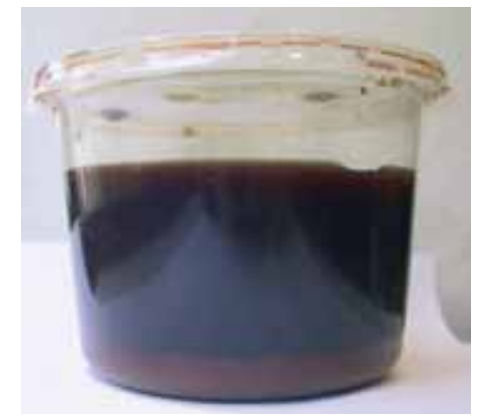

Fig 7 The dark brown urine of patient $C$ on October 19 Dunkelbrauner Urin von Patient C am 19. Oktober

ned a lot of dry faeces. Haematology and blood biochemistry values are provided in Table 3.

The horse was treated with mineral oil (2 litre per nasogastric tube) and flunixine meglumine. As neurological problems were included among the differential diagnoses, the horse was also treated with thiamine ${ }^{10}(2 \mathrm{mg} / \mathrm{kg}$ sid i.v. for three days).

The next morning, October 19, the horse was recumbent and unable to rise (Figure 6). Respiratory rate was 18 breaths/min, the heart rate was 56 beats/min and the rectal temperature was $37.3^{\circ} \mathrm{C}$. Further clinical examination, including a neurological exam, revealed no abnormalities. However, after the horse had risen with some help, it started to sweat and to tremble severely and lay down within 10 minutes. Further questioning of the owner revealed that the horse had a history of recurrent episodes of rhabdomyolysis. Urinary catheterisation revealed dark brown urine (Figure 7). Intravenous administration of saline, lactated ringer's solution, and a calcium-magnesium solution was started and flunixin meglumine and acepromazine were given. To prevent complications involving the permanent intravenous catheter treatment with trimethoprim sulphadoxine was also started. During the night the situation deteriorated and on October 20 it was decided to euthanise the horse and to perform a post-mortem examination.

At necropsy degeneration of many muscles was macroscopically visible (Figures 8 and 9) and histology revealed severe degeneration and necrosis of striated muscle tissue with increased cellularity (Figures $10 \mathrm{a}$ and b).

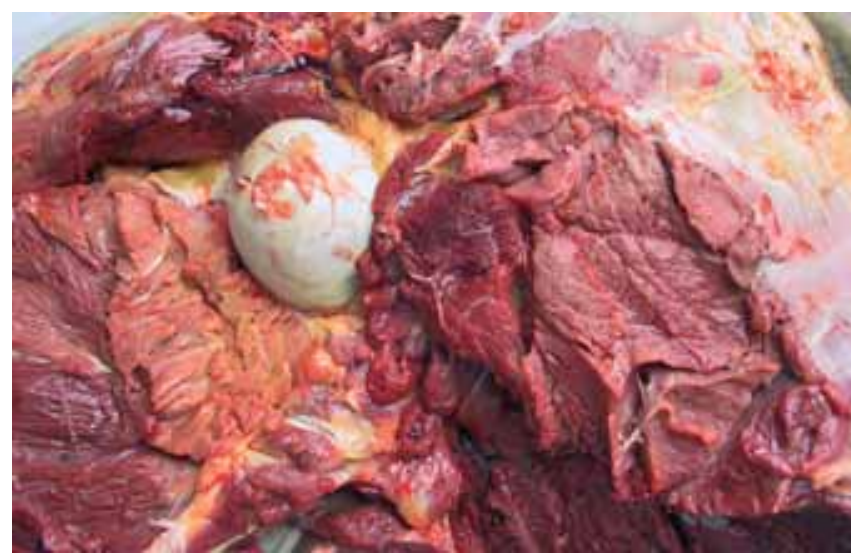

Fig 8 Patient $\mathrm{C}$ - severely degenerated muscles around the hip joint Pat. C mit hochgradiger Muskeldegeneration im Bereich des Hüftgelenks

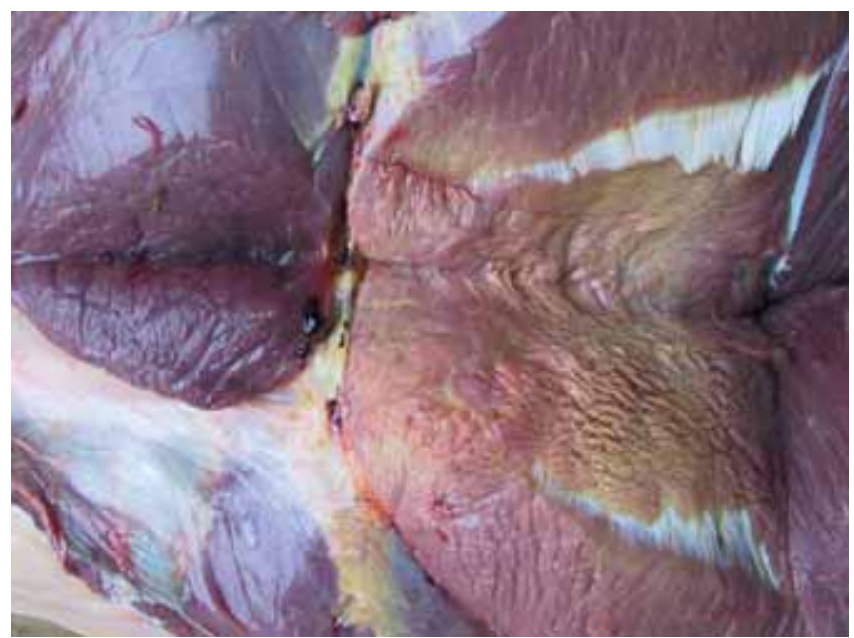

Fig 9 Patient $\mathrm{C}$ - severely degenerated muscles around stifle Patient C mit ausgeprägter Muskeldegenerataion im Bereich des Knies

\section{Case D}

On October 21, a 5-year old Icelandic gelding (estimated weight $350 \mathrm{~kg}$ ) was admitted to the University clinic for severe lameness of the left hind limb. The horse had been castrated 3 days earlier, on October 18, in a private equine clinic, and had suffered a poor recovery after anaesthesia. During this unsupervised recovery the horse may have fallen. The horse had been treated with thiamine and corticosteroids in the private clinic, and sent home on October 19, still showing a stiff, short gait with decreased protraction of the left hind limb. The veterinarian prescribed a 3-day course of NSAIDs but the owner did not feel comfortable with the situation and made an appointment for a lameness examination at the University clinic for the morning of October 22. However, as the owner did not wish to travel in the morning rush-hour he delivered the horse (and another horse to keep it company as the patient could not be without this friend) on October 21, at 21.30 hour. 
On arrival a brief clinical examination revealed no abnormalities except the lameness of the left hind limb and both horses were stabled in two adjacent stalls. The next morning, October 22, further orthopaedic examination of the left hind limb revealed no abnormalities. However, when the horse was walked after the examination it fell down and was unable to rise. Clinical examination by an internal medicine clini-
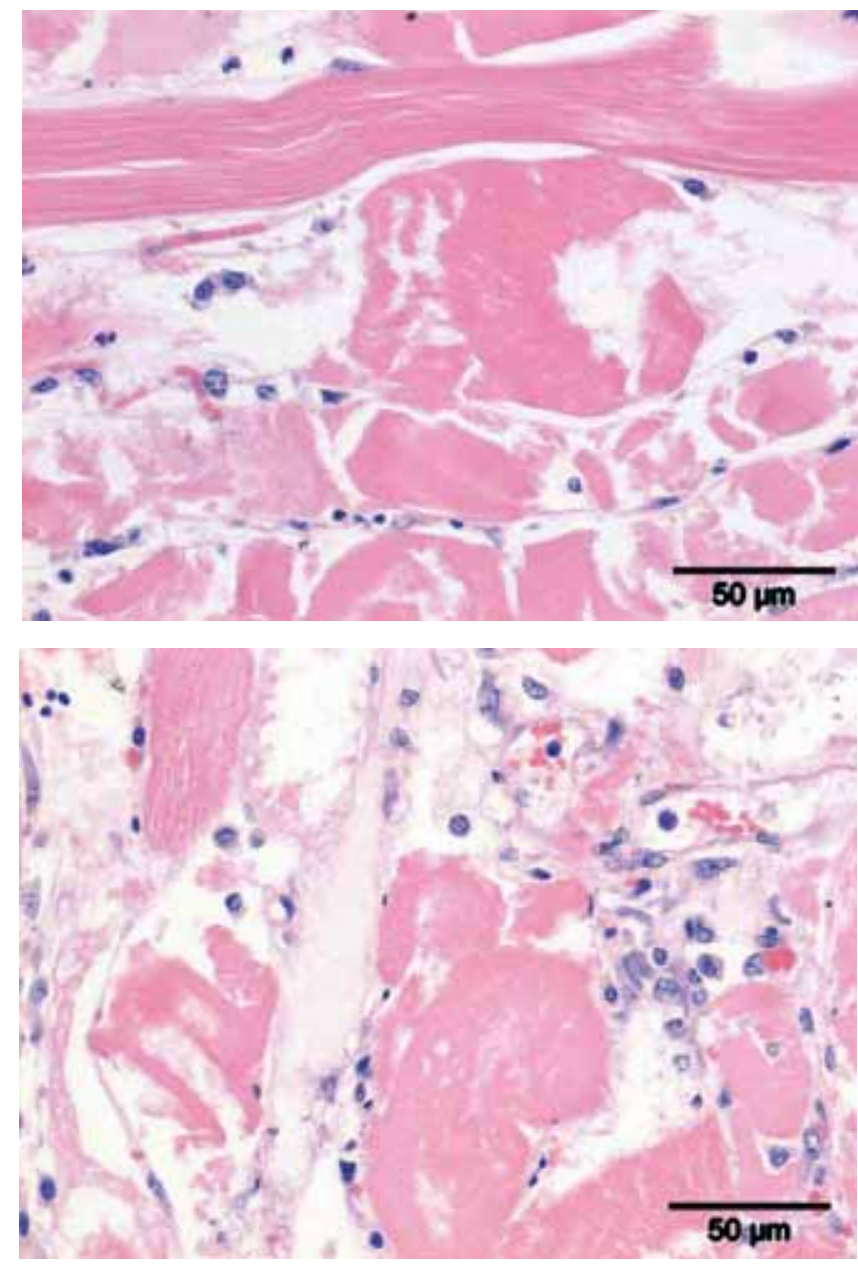

Fig $10 \mathrm{a}$ and $\mathrm{b}$ Histology samples of patient $\mathrm{C}$ - severe degeneration and necrosis of striated muscle tissue (above) and also increased cellularity (below) H\&E.

Histologie von Patient C mit hochgradiger Degeneration und Nekrose der quergestreiften Muskelfasern(oben) und hochgradigem Zellgehalt (unten) HE.

cian revealed a respiratory rate of 90 breaths/min, a heart rate of 76 beats/min and a rectal temperature of $38.4{ }^{\circ} \mathrm{C}$. The muscles of the back and the left gluteal area were very hard and slightly painful. Urine collected by catherisation was dark brown and contained a lot of protein. Haematology and biochemistry (Table 4) showed that the muscle enzyme concentrations were severely elevated. Treatment with saline infusion, acepromazine and flunixin meglumine was started immediately. Regrettably, the horse did not accept its recumbent position and continued to fight to rise, despite the fact that its 'friend' (the companion horse) was in the same, very large stall (Figure 11). Several therapeutics were used to try to sedate the horse sufficiently to prevent it fighting. Diaze$\mathrm{pam}^{11}(0.06 \mathrm{mg} / \mathrm{kg}$ i.v.) did not have enough effect and detomidine $^{12}\left(0.01 \mathrm{mg} / \mathrm{kg}\right.$ i.v.) with midazolam ${ }^{13}(0.06 \mathrm{mg} / \mathrm{kg}$ i.v.) also did not prevent the horse's severe struggling. Guai- fenesin ${ }^{14}(100 \mathrm{mg} / \mathrm{kg}$ i.v.) in combination with thiopentalsodium $^{15}$ (5 mg/kg i.v.) had a sufficient effect. However, in the meantime, the owner had arrived at the clinic and, considering the poor prognosis, euthanasia seemed the best option.

Table 4 Haematology and blood biochemistry of patient D. n.d. = not determined

Hämatologie und Blutchemie von Patient D. n.d. = nicht untersucht

\begin{tabular}{|c|c|c|}
\hline & $22 / 10$ & $\begin{array}{c}\text { Reference } \\
\text { values }\end{array}$ \\
\hline PCV (I/I) & 0.42 & $0.32-0.42$ \\
\hline WBC (G/I) & 7.9 & 7.0-10.0 \\
\hline $\mathrm{pH}$ & 7.460 & 7.35-7.45 \\
\hline $\mathrm{pCO}_{2}(\mathrm{kPa})$ & 5.3 & $4.7-6.0$ \\
\hline $\mathrm{HCO}_{3}^{-}(\mathrm{mmol} / \mathrm{I})$ & 28.0 & $20-28$ \\
\hline $\mathrm{BE} \quad(\mathrm{mmol} / \mathrm{l})$ & +4.3 & -3 to +3 \\
\hline CK $(\mathrm{mmol} / \mathrm{l})$ & 129,167 & $<200$ \\
\hline AST $(\mathrm{mmol} / \mathrm{I})$ & 12,438 & $125-275$ \\
\hline $\mathrm{LDH} \quad(\mathrm{mmol} / \mathrm{l})$ & 48,297 & $150-420$ \\
\hline Lactate $(\mathrm{mmol} / \mathrm{I})$ & 2.8 & $0.7-1.2$ \\
\hline Glucose $(\mathrm{mmol} / \mathrm{l})$ & 8.1 & $3.9-5.6$ \\
\hline Urea $(\mathrm{mmol} / \mathrm{l})$ & 6.3 & $<8$ \\
\hline $\mathrm{Ca}^{++}(\mathrm{mmol} / \mathrm{I})$ & 1.4 & $1.4-1.7$ \\
\hline
\end{tabular}

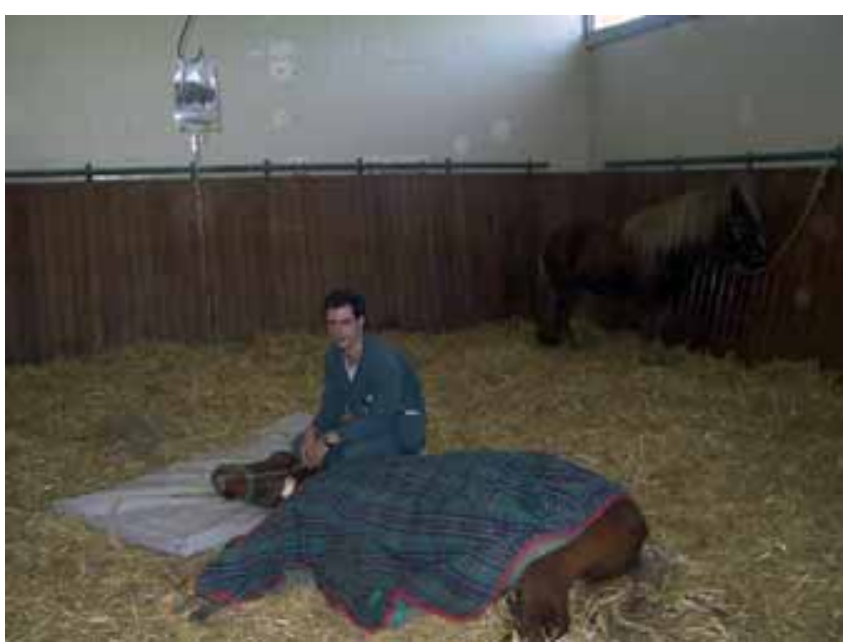

Fig 11 Patient $D$ was unable to rise but continuously fought to get up Patient kämpfte ständig vergebens aufzustehen.

The owner accepted this advice. Post mortem examination revealed very extensive rhabdomyolysis in all four limbs (Figures 12 and 13), but no other abnormalities. Histology showed severe degeneration and necrosis of striated muscle tissue. The muscle tissue was infiltrated with numerous monocytes, macrophages and other inflammatory cells. Also, some proliferation of fibroblasts was visible (Figures 14 and 15). Less affected adjacent muscle fibers showed presence of cross-striation. The castration wounds showed no abnormalities.

\section{Discussion}

The four cases presented in this report represent four different breeds and a different history. In retrospect, none of the four horses should have been referred to the University cli- 


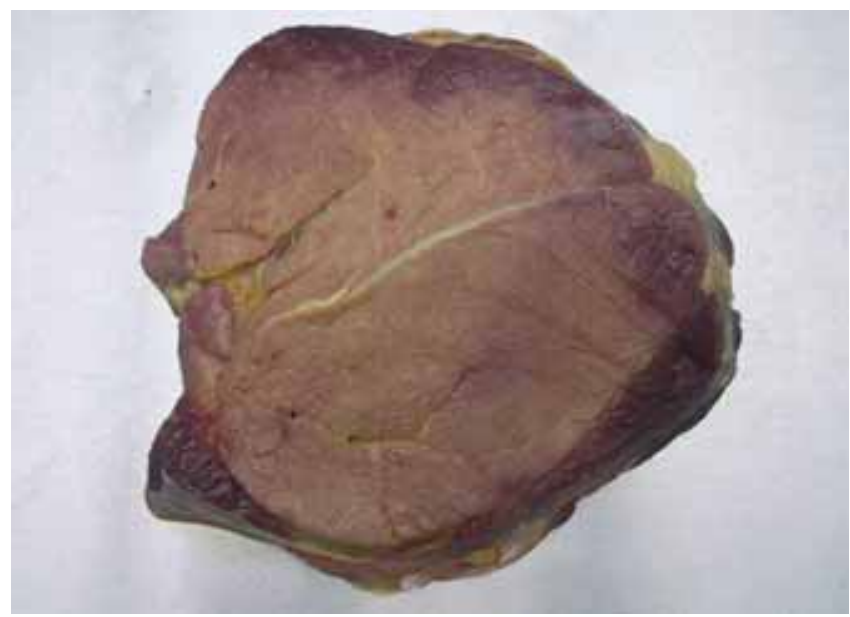

Fig 12 Severely degenerated muscles (pale) around the shoulder of patient D.

Hochgradige Muskeldegeneration (blass) im Bereich der Schulter bei Patient D

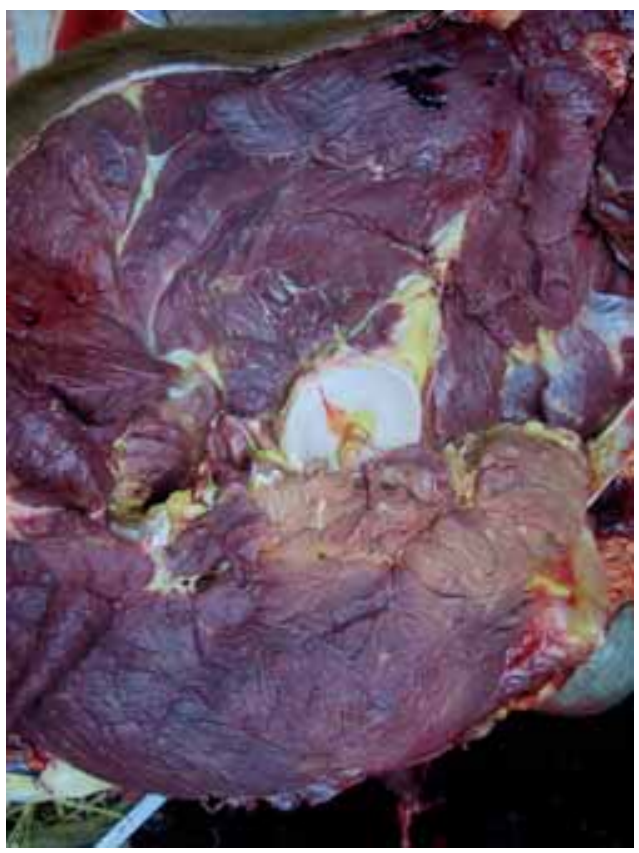

Fig 13 Severely degenerated muscles (pale) around the hip joint of patient D.

Starke Muskeldegenetaion i(blass) m Bereich des Hüftgelenks bei Patient D

nic. If at all possible, treatment at the horse's current location is preferable and improves the prognosis. In one case the diagnosis had been reached at home (case B), in the other three cases the diagnosis was made either on arrival or the next morning. Rhabdomyolysis should always be included as a differential diagnosis in a horse with vague colic or neurological signs.

The PCV was increased in two cases and normal in the other two, but all four cases showed myoglubinuria and needed considerable amounts of intravenous fluids for that reason. In all four cases muscle enzyme activities (CK and AST) were dramatically increased and in the two surviving cases the AST activity took weeks to return to normal. The venous $\mathrm{pH}$ values of all four cases showed either respiratory acidosis or were within normal limits. The blood lactate concentration
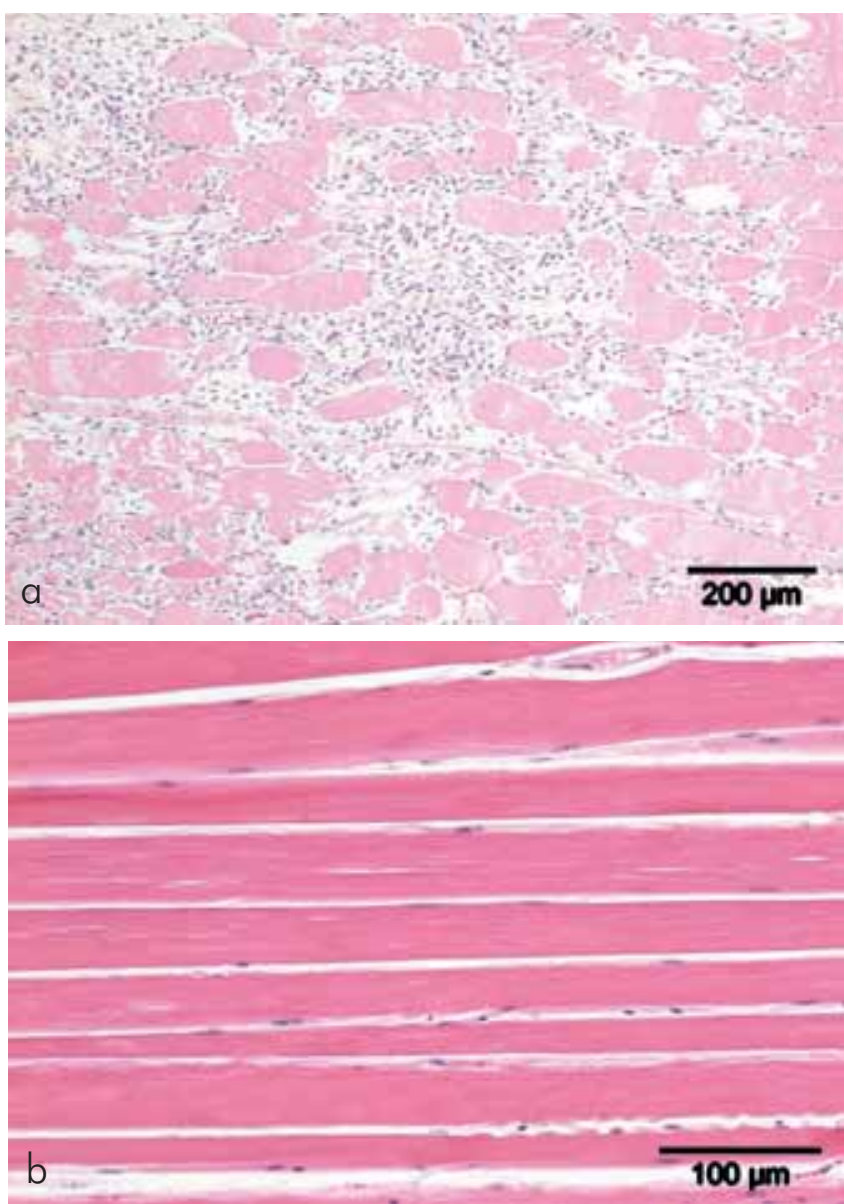

Fig $14 a$ and $b$ Patient D - severe degeneration and necrosis of striated muscle tissue (above); note also the increased cellularity compared to normal muscle tissue (below) H\&E.

Hochgradige Degeneration und Nekrose der quergestreiften Muskulfasern (oben) und erhöhtem Zellgehalt im Vergleich zum gesunden Muskelgewebe (unten) bei Patient D. HE

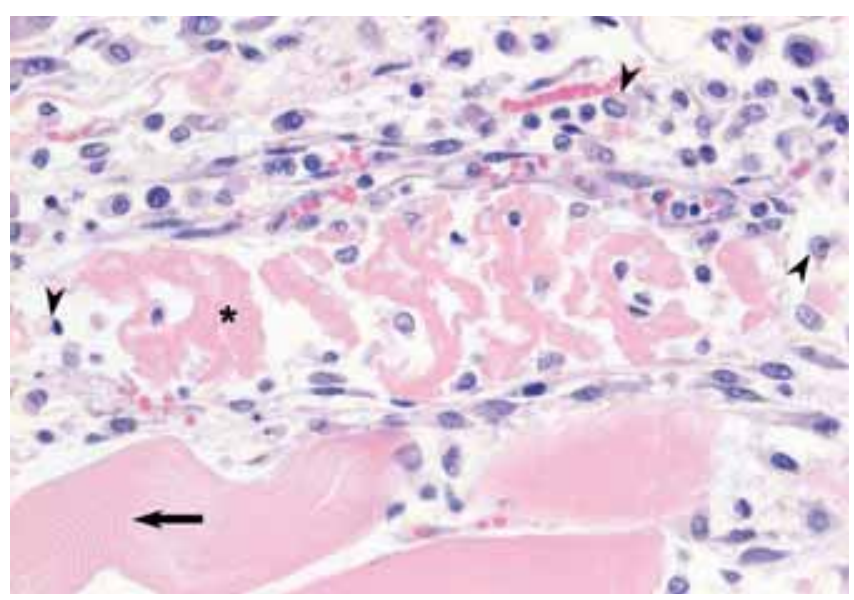

Fig 15 Patient D - severe degeneration and necrosis of striated muscle tissue; in the center a fragmented muscle fiber (asterisk); muscle tissue is infiltrated with numerous monocytes and macrophages (arrowheads) and other inflammatory cells; also, some proliferation of fibroblasts is visible; note cross-striation in a less affected adjacent muscle fiber (arrow) H\&E.

Patient D - Hochgradige Degeneration und Nekrose der quergestreiften Muskulfasern. In der Mitte eine fragmentierte Muskelfaser (Stern). Das Muskelgewebe ist mit zahlreichen Monozyten, Makrophagen (Pfeilspitzen) und anderen Entzündungszellen infiltriert. Auch sind einige Fibroblasten sichtbar. Beachte die Querstreifung in einer weniger betroffenen Muskefaser (Pfeil) HE. 
was elevated in all four animals, probably as result of anaerobic metabolism in the affected muscles. The elevated glucose concentration as found in all four cases is probably a result of the significant stress associated with the condition. Sodium and chloride concentrations were normal in the three cases in which they were determined. Potassium concentration was decreased in one case and ionised calcium concentration was decreased in two patients. Considering all haematology and biochemistry results it is clear that these variables can help to confirm the diagnosis of myopathy, but in practice it is certainly possible to reach a tentative diagnosis without this information.

\section{Conclusions}

Advice to aid diagnosis and treatment of equine patients with rhabdomyolysis:

- Establish the diagnosis as soon as possible and always bear in mind the possibility of rhabdomyolysis in every case of vague neurological complaints or colic signs.

- Rest the horse immediately, so do not walk the horse home or transport it by trailer, but provide the horse with a comfortable place to stand and lie down as soon and as nearby as possible.

- If the horse is unable to rise, make it as comfortable as possible on a thick straw or peat bed and try to prevent struggling, preferably by 'talking to the horse', and if that does not work use sedatives; turn the horse on its other side every four hours (with sufficient assistance) to prevent ischemia of the muscles and pressure sores.

- Place a permanent intravenous catheter and provide continuous iv infusion with saline until the urine has retained its normal colour (yellow).

- Treat the acutely diseased patient with NSAIDs to prevent pain and to decrease inflammation (be careful in hypovolaemic patients) and use acepromazine to provide some tranquillisation and peripheral vasodilatation

- Feed the horse a limited amount of good-quality hay and no concentrates and discuss with the owner the future ration, containing less carbohydrates and more fat.

- Start hand-walking as soon as muscle enzyme activities have decreased significantly.

- Start training as soon as muscle enzymes have returned to normal.

- Supplement vitamin E, which may be helpful in the prevention of further episodes and is not considered as 'doping'.

Last but not least: the best cure for rhabdomyolysis is prevention, and the next best is recognition at an early stage.

\section{Manufacturer's addresses}

1 Finadyne ${ }^{\circledR}$, Schering-Plough B.V., Maarssen, The Netherlands (patient $A$ and $B$ )

Bedozane ${ }^{\circledR}$, Eurovet Nederland B.V., Bladel, The Netherlands (patients C and D)

2 Vetranquil ${ }^{\circledR}$, Sanofi, Maassluis, The Netherlands

3 Borgal $^{\circledR}$, Hoechst Roussel Vet. N.V., Brussel, Belgie

4 Quadrisol 100 ${ }^{\circledR}$, Intervet Nederland B.V., Boxmeer, The Netherlands

5 Tocopherol acetate oil, University pharmacy product with 900 $\mathrm{mg} / \mathrm{ml}$

6 Sultrisan Orale Pasta ${ }^{\circledR}$, Anisane, Dopharma, Raamsdonkveer, The Netherlands

7 Heparine ${ }^{\circledR}$, Leo Pharmaceutical Products, Weesp, The Netherlands

8 Carbasalatum calcicum ${ }^{\circledR}$, Genfarma B.V.,

9 Excenel $^{\circledR}$, Pharmacia \& Upjohn, Woerden, The Netherlands

10 Thiamine- $\mathrm{HCl}$, Univeristy pharmacy product with $100 \mathrm{mg} / \mathrm{ml}$

11 Diazepam CF ${ }^{\circledR}$, Centrafarm B.V., Etten-Leur, The Netherlands

12 Domosedan $^{\circledR}$, Pfizer Animal Health B.V., Capelle aan de ljssel, The Netherlands

13 Dormicum ${ }^{\circledR}$, Roche Nederland B.V., Woerden, The Netherlands

14 Gujatal $^{\circledR}$, Eurovet Nederland B.V., Bladel, The Netherlands

15 Nesdonal $^{\circledR}$, Merial B.V., Velserbroek, The Netherlands

\section{References}

Beech J. (1997): Chronic exertional rhabdomyolysis. In: Selected neurological and muscular diseases. Eds. J. Löfstedt and C. Collatos. Vet. Clinics of North Am. Equine Practice 13, 145-168

Beech J. (2000): Equine muscle disorders 1: chronic intermittent rhabdomyolysis. Equine vet. Ed. 12, 163-167

Bertone J. J. and L. J. I. Horspool (2004): Equine clinical pharmacology. Saunders, Edinburgh, pp. 367-380

Brown C. M and J. J. Bertone (2002): Rhabdomyolysis. In: The 5minute veterinary consult equine. Lippincott Williams \& Wilkins, Baltimore, pp. 926-927

MacLeay J. M. (2004): Diseases of the musculoskeletal system. In: Equine internal medicine. Eds. S.M. Reed, W.M. Bayly and D.C. Sellon, Saunders, St. Louis, pp. 461-522

Sloet van Oldruitenborgh-Oosterbaan M. M. and L. S. Goehring (2000): Muskel und Muskelerkrankungen beim Pferd. Pferdeheilk. $16,394-404$

Valberg S. J. (1996): Muscular causes of exercise intolerance in horses. In: Exercise intolerance. Ed. E.M. Gaughan. Vet. Clinic North Am. Equine Practice 12, 495-515

Marianne M. Sloet van Oldruitenborgh-Oosterbaan DVM, PhD, Dipl. ECEIM, Spec. KNMvD Equine Internal Medicine Department of Equine Sciences Faculty of Veterinary Medicine Yalelaan 114, 3584 CM Utrecht The Netherlands m.sloet@vet.uu.nl

\section{Pferdeheilkunde Curriculum Berlin}

\section{Herz- und Gefäßkrankheiten}

Heidrun Gehlen und Peter Stadler

14.-15. Oktober 2006

www.humboldt-curricula.com 